\title{
Гидрогеологические и геотектонические особенности надсолевых верхнепалеозойско- мезозойско-кайнозойских палеобассейнов Прикаспийского соляно-купольного региона
}

\author{
Н.Г. Мязина \\ Оренбургский государственный университет, \\ 460018, Оренбург, пр. Победы, 13, кафедра геологии \\ E-mail: miazinanatalia@ rambler.ru \\ (Статья поступила в редакиию 28 января 2015 г.)
}

\begin{abstract}
Рассмотрены закономерности формирования и размещения подземных вод и рассолов надсолевого этажа Прикаспийского гидрогеологического мегабассейна. Исследован качественный состав подземных рассолов вод осадочного чехла надсолевого комплекса. Проанализированы результаты минерализации, ионносолевой состав. Дана характеристика основных геохимических и генетических типов рассолов. Выявлена вертикальная зональность изменения ионно-солевого состава с глубиной. Обоснована возможность комплексного использования рассолов и вод надсолевого комплекса.

Ключевые слова: Прикаспийский мегабассейн, надсолевой этаж, подземные воды, рассоль, химический состав, минерализаџия.
\end{abstract}

DOI: $10.17072 /$ psu.geol.26.38

\section{Введение}

Прикаспийский гидрогеологический мегабассейн в тектоническом отношении представляет собой наложенную впадину Восточно-Европейской платформы. Надсолевой этаж формировался в замкнутом морском бассейне.

Палеозойский эвапоритовый (солевой) бассейн сформировался на синколлизионной (инверсионной) стадии, которая явилась решающей в развитии тектоно-седиментационных процессов внутри бассейна. В нижнепермское время морской бассейн был окончательно изолирован от обширного океана Палеотетиса в результате захлопывания уральской части и возникновения на его месте орогена. Складчатый пояс Урала и южная часть
Мугоджар создали преграду на востоке морскому бассейну Прикаспийской впадины. Кунгурский эвапоритовый этаж является региональным водоупором для Прикаспийского нефтегазоносного бассейна.

В кунгурский век в аридной зоне Прикаспийской впадины происходило интенсивное соленакопление. Первичная мощность соленосных отложений достигала 2-4 км. При этом наряду с каменной солью (галитом) отлагались калийные и магниевые соли. В результате этих процессов с солями были захоронены огромные количества высококонцентрированных (до 350-540 г/дм ${ }^{3}$ ) металлоносных рассолов, которые проникали и в нижележащие отложения. 
Данные исследований и их обсуждение

Надсолевой этаж представлен: 1) верхнепалеозойским (эвапоритовым) гидрогеологическим бассейном пластовотрещинных вод, 2) мезозойским бассейном напорных, пластовых и пластовотрещинных вод, 3) кайнозойским (палеоген-неоген-четвертичный) гидрогеологическим бассейном напорно-безнапорных порово-пластовых, пластовых и пластовотрещинных вод. Каждый из выделенных гидрогеологических бассейнов характеризуется различными видами гидрогеологической зональности.

В верхнепермское время уфимского века поздней перми продолжалось соленакопление в Прикаспийской впадине и прилегающих частях. В конце уфимского века в восточной части в континентальных аллювиально-дельтовых и озерных обстановках накапливались в основном красноцветные терригенные толщи до нескольких десятков метров (в западных районах Прикаспийской синеклизы). В начале казанского века в связи со значительным опусканием восточной части Восточно-Европейской платформы во впадине возникает обширный внутриконтинентальный водоем, сообщавшийся проливом с бассейном Баренцева моря. В нем накапливались терригенные и карбонатные осадки мощностью до 50-100 м.

В конце казанского века во внутриконтинентальном морском водоеме соленость вод резко повысилась (в связи с его изоляцией), о чем свидетельствует появление в разрезе верхнеказанских отложений ангидритов и прослоев галита. Наиболее сильное засолонение вод бассейна происходило в Прикаспийской впадине.

В татарский век большая часть территории, обрамляющей Прикаспий, представляла обширную наземную аккумулятивную равнину, в которой накапливались аллювиальные, пролювиальные и озерные, в основном терригенные, красноцветные осадки мощностью до 400 м. С ними захоронялись в основном соленые воды сульфатного, хлоридно-сульфатного состава с минерализацией до $10-15$ г/дм ${ }^{3}$ (реже до 70 г/дм ${ }^{3}$ ). Позднепермскотриасовый этап ознаменовался началом формирования соляной тектоники в пределах Прикаспийской синеклизы. Под действием гравитационных и тектонических факторов происходили пространственное перераспределение кунгурских соляных масс и образование соляных антиклиналей и разделяющих их прогибов.

Мезозойский бассейн напорных, пластовых и пластово-трещинных вод формировался на постколлизионной компенсационной $\left(\mathrm{P}_{2}-\mathrm{T}\right)$, а затем на плитной стадии (J-P-Q) в мелководных морских, а затем в наземных условиях осадконакопления, сопровождался медленным погружением впадины. С конца перми - начала триаса начинается седиментационный механизм развития опусканий под действием нагрузки мощных толщ осадков. Его действие проявилось в виде прогибаний в зоне сочленения континентальной и субокеанической литосферы. В дальнейшем в пределах впадины развивались медленные опускания, компенсировавшиеся накоплением наземных и мелководных морских отложений. К середине триасового периода была достигнута компенсация, впадина была заполнена осадками. На территории бассейна формировалась солянокупольная тектоника - более 1700 соляных куполов, образовавших ячеистосотовую структуру с межкупольными депрессиями-мульдами, а в краевых частях расположились соляные отроги и валы. Соляно-купольный диапиризм способствует резкому изменению пластовых параметров на коротких расстояниях, где могут проявляться гидрохимические и гидродинамические аномалии. В бассейне сформировалась литостатическая водонапорная система, происходило выжимание жидкости из уплотняющихся осадков в коллекторы. Мезозойская элизионная система 
закрытая. В составе бассейна распространены: 1) триасовый терригенный ВК (T), 2) средне-верхнеюрский терригенный ВК $\left.\left(\mathrm{J}_{2-3}\right), 3\right)$ нижнемеловой терригенный ВК $\left.\left(\mathrm{K}_{1}\right), 4\right)$ 4)вернемеловой карбонатно-терригенный $\mathrm{BK} \quad\left(\mathrm{K}_{2}\right)$ комплексы. В бассейне присутствуют седиментационные воды разной минерализации от десятков до 200-250 г/дм ${ }^{3}$ в нижней части разреза, главным образом хлоридные натриевые рассолы хлоркальциевого типа. Водоносные комплексы развиваются в межсолевых мульдах и прогибах, представляют гидродинамику локальных замкнутых бассейнов. Хлоридные рассолы мезозойского возраста распространены в Прикаспийской впадине и в прибортовой зоне сочленения с Воронежской антеклизой в Каракульско-Смушковской зоне дислокаций и т.д. Надсолевые рассолы представлены основными геохимическими и генетическими типами: хлоридными натриевыми и натриево-кальциевыми (кальциево-натриевыми) инфильтрогенными и седиментогенными рассолами. В вертикальном разрезе Прикаспийской впадины верхнеепалеозойские и мезозойские рассолы занимают нижнюю зону надсолевой части гидрогеодинамической системы (рис.). Хлоридные натриевые седимента-ционные и сульфидно-углекисло-метаново-азотные инфильтро-генные рассолы выщелачивания каменных солей установлены вблизи примыкания водоносных горизонтов к соляным куполам с минерализацией 37-320,0 г/дм ${ }^{3}$, обедненным $\mathrm{Br}(0,03-0,3$ г/дм $\left.{ }^{3}\right)$. Плотность рассолов 1,04-1,102 $\Gamma / \mathrm{cm}^{3}$.

Хлоридные натриевые, йодобромные азотно-метановые рассолы встречены на глубинах 587-3050 м с минерализацией 43,15-261,76 г/дм³ , обедненные $\mathrm{Br}$ (46286мг/дм $\left.{ }^{3}\right)$. Плотность рассолов 1,01-1,196 $\Gamma / \mathrm{cm}^{3}$.

Хлоридные натриево-кальциевые и кальциево-натриевые, йодобромные азотно-метановые рассолы установлены в карбонатно-терригенных отложениях мезозоя на глубинах 587-2640м с минерализацией 101-179 г/дм ${ }^{3}$, обедненные $\mathrm{Br}$ (70410мг/дм $\left.{ }^{3}\right)$. Плотность рассолов 1,0651,123 г $/ \mathrm{cm}^{3}$. Содержание хлоридов кальция в мезозойских рассолах 2-16 \%-экв.

В процессе геологического круговорота седиментогенные растворы вовлекаются в сложный процесс литогенетического преобразования осадочных пород, которые с момента захоронения этих растворов выступают основным источником растворенных веществ. Формирование вод седиментационного цикла определяется захоронением морских вод, степенью их метаморфизации и литолого-минералогическим составом водовмещающих пород.

В надсолевом этаже в мезозойских и кайнозойских морских терригенных и карбонатных толщах вне $30 н$ влияния соляных куполов и выше межкупольных депрессий содержатся седиментогенные хлоридные натриевые воды и рассолы с минерализацией до 40 г/дм ${ }^{3}$, реже до 100 г/дм ${ }^{3}$ и выше.

При пластоиспытании нефтяной скважины № 5038 Гмелинской с глубины 587593 м из туронских отложений верхнего мела выведены притоки слабометаморфизованных $(\mathrm{rNa} / \mathrm{rCl}=0,83)$ седиментогенных хлоридных натриевых рассолов $\mathrm{Cl}-\mathrm{Ca}$ типа ІІІб (по Е.В. Посохову, В.А. Сулину) с содержанием $\mathrm{Ca}$ 12\%-экв. Химический состав представлен следующей формулой:

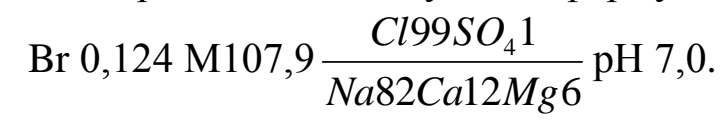

При погружении триасовых пород в Прикаспийскую впадину слабые рассолы переходят в крепкие рассолы и приобретают хорошо выраженный хлоркальциевый тип $(\mathrm{rNa} / \mathrm{rCl}=0,54)$. При пластоиспытании нефтяной скважины № 10 на Паромненской площади с глубины 2119-2134м из баскунчакских отложений нижнего триаса выведены притоки метаморфизованных седиментогенных хлоридных кальциево-натриевых рассолов Cl-Cа типа ІІІб (по Е.В. Посохову, В.А. Сулину) с содержанием Са 33\%-экв. 


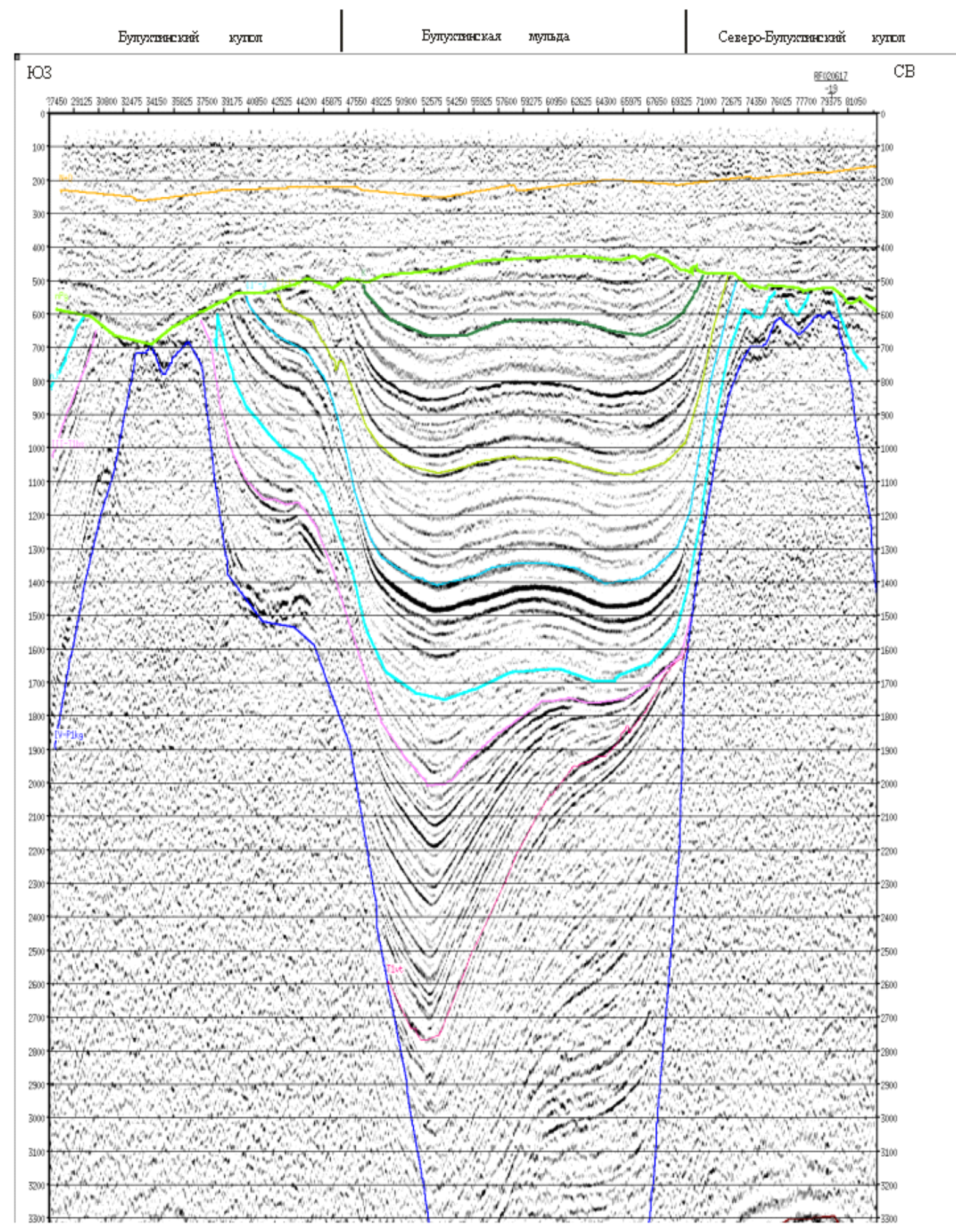

Фрагмент временного мигрированного разреза регионального профиля RF 020617 стратиграфического выполнения межкупольных депрессий Кайсаиякой соляно-купольной зоны 
Химический состав представлен следующей формулой:

$$
\text { Br 0,41 M209,1 } \frac{C l 100}{N a 54 C a 33 M g 13} \mathrm{pH} 4,7 \text {. }
$$

На восточном крыле впадины верхнепермские и триасовые отложения объединены в пестроцветную терригенную толщу мощностью до 1,5 км. Водоносность пород разнообразная. В районах неглубокого залегания толщи вскрываются солоноватые воды сульфатно-хлоридного натриевого состава, с глубиной минерализация достигает 350 г/дм ${ }^{3}$. По мере перемещения вод к центральной части бассейна минерализация возрастает, уменьшается $\mathrm{rNa} / \mathrm{rCl}$, увеличивается содержание йода, брома. Основной областью разгрузки подземных вод являются внутренние районы впадины и акватория Каспия. Во внутренних районах бассейна разгрузка водоносных комплексов происходит по зонам тектонических нарушений и в долинах рек и озер, лиманов, где дренируют соляные купола. В центральной части в междуречье Волги и Урала в рассолах и подземных водах растворены метановые газы, а в прибортовой зоне азотнометановые и реже азотные.

\section{Выводы}

Подземные рассолы надсолевой толщи представляют большую практическую ценность. Рассолы можно использовать как поликомпонентное, бальнеологи-ческое и гидроминеральное сырье.

В эвапоритовом бассейне, испытывающем интенсивное погружение за счет широкого развития зон растяжения, в надсолевом этаже образуются солянокупольные ловушки от триаса до палеогена. Промышленная нефтегазоносность установлена в триасовых и юрскомеловых отложениях южных частей Прикаспийской впадины.

Для обоснования и оптимизации геологоразведочных работ и оценки гидрогеологических условий при прогнозе нефтегазоносности необходимо учитывать особенности геологогидрогеологического строения солянокупольных территорий.

\section{Библиографический список}

1. Мязина Н.Г. Закономерности формирования и распространения минеральных вод в гидрогеологических структурах Волгоградской области: монография. Волгоград: Изд-во ВолГУ, 2008. 212 с.

2. Мязина Н.Г. Вертикальная гидрогеохимическая зональность подземных вод Прикаспийской впадины // Геология, география и глобальная энергия. Астрахань, 2013. №4 (51). С. 59-64.

3. Мязина Н.Г. Гидрогеохимические особенности рассолов надсолевого комплекса Прикаспийской синеклизы // Геология, география и глобальная энергия. Астрахань, 2013. №4 (51). С. 96-100.

4. Мязина Н.Г. Влияние тектогенеза и галогенеза на геохимические особенности рассолов Прикаспийской синеклизы (СевероКаспийский артезианский бассейн) // Вестник ОГУ. 2014. № 1 (155). С. 136-145.

5. Мязина Н.Г. Внутри- и межсолевые рассолы кунгурских отложений Прикаспийской синеклизы // Геология, география и глобальная энергия. Астрахань, 2014. № 2. C. 57-65. 


\title{
Hydrogeological and Geotectonic Features of the Post-salt Upper Paleozoic-Mesozoic-Cenozoic paleobasins of the Pre-Caspian Salt Dome Region
}

\author{
N.G. Myazina \\ Orenburg State University, Department of Geology, 13 Victory Str., Orenburg \\ 460018, Russia \\ E-mail: miazinanatalia@ rambler.ru
}

The article describes the regularities of formation and distribution of groundwater and brines in the post-salt layers of the Caspian hydrogeological megabasin. Author investigated the qualitative composition of underground brine of sedimentary cover water of the post-salt complex. The results of analysis and typification of the mineralization and ionic composition of saline waters are presented. The basic geochemical and genetic types of brines were characterized. Vertical zonation of ionic saline composition with a depth was identified. The author demonstrate a possibility of complex use of brines and waters of the post-salt strata.

Keywords: Caspian megabasin; post-salt; ground water; brines; chemical composition; mineralization.

\section{References}

1. Myazina N. G. 2008. Zakonomernosti formirovaniya i rasprostraneniya mineralnykh vod $\mathrm{v}$ gidrogeologicheskikh strukturakh Volgogradskoy oblasti [Regularities of formation and distribution of mineral waters in the hydrogeological structures of the Volgograd region]. Volga Publ., Volgograd, 212 p. (in Russian)

2. Myazina N. G. 2013. Vertikalnaya gidrogeokhimicheskaya zonalnost podzemnykh vod Prikaspiyskoy vpadiny [Vertical hydrogeochemical zonation of groundwater of the Caspian basin]. Geologiya, geografiya i globalnaya energiya. 4 (51): 59-64. (in Russian)

3. Myazina N. G. 2013. Gidrogeokhimicheskie osobennosti rassolov nadsolevogo kompleksa Prikaspiyskoy sineklizy [Hydrogeochemical features of brines of post-salt complex of the
Pre-Caspian syneclise]. Geologiya, geografiya i globalnaya energiya. 4 (51): 96-100. (in Russian)

4. Myazina N. G. 2014. Vliyanie tektogeneza i galogeneza na geokhimicheskie osobennosti rassolov Prikaspiyskoy sineklizy (SeveroKaspiyskiy artezianskiy basseyn) [The influence of tectogenesis and halogenesis on the geochemical characteristics of brines of the PreCaspian syneclise (North-Caspian artesian basin)]. Vestnik OGU. 1 (155): 136-145. (in Russian)

5. Myazina N. G. 2014. Vnutri I mezhsolevye rassoly kungurskikh itlozheniy Prikaspiyskoy sineklizy [Intra- and interstratal brines of Kungur sediments of the Pre-Caspian syneclise]. Geologiya, geografiya i globalnaya energiya. 2: 57-65. (in Russian) 